\title{
Insider trading and future stock returns in firms with concentrated ownership levels
}

\author{
Dimitris K. Chronopoulos ${ }^{\mathrm{a}}$, David G. McMillan ${ }^{\mathrm{b}}$, Fotios I. Papadimitriou ${ }^{\mathrm{c}^{*}}$, \\ Manouchehr Tavakoli ${ }^{\mathrm{a}}$ \\ ${ }^{\text {a }}$ School of Management, University of St Andrews \\ ${ }^{\mathrm{b}}$ School of Management, University of Stirling \\ ${ }^{\mathrm{c}}$ Business School, University of Aberdeen \\ Forthcoming in the European Journal of Finance
}

\begin{abstract}
We investigate the relationship between insider trading and stock returns in firms with concentrated ownership. To this end, we employ data from East Asian countries which span the period 2003:01-2012:05. Consistent with previous literature, we find a significantly negative relation between the selling activity of insiders and stock returns. However, contrary to studies which focus on highly developed markets, we find that the buying activity of insiders is also inversely related to future stock returns. Our analysis shows that top directors with higher ownership levels drive this result, suggesting that the trading activity of insiders is not always associated with profit making motives and can be explained by their level of ownership. Furthermore, we demonstrate that a trading strategy which focuses solely on purchases made by top directors with high ownership levels yields negative returns. The paper has important implications for outside investors who mimic the trading activity of insiders with the aim to realise profits.
\end{abstract}

JEL Classification: G12; G14; C53

Keywords: Insider trading, Stock returns, Economic value, Trading strategies

\footnotetext{
* Corresponding author: Business School, University of Aberdeen, Aberdeen, AB24 3QY, Scotland, UK. Email: fotios.papadimitriou@abdn.ac.uk; Tel: +44 (0)1224 273825.
} 


\section{Introduction}

A rich literature on insiders' trading shows that insiders can earn abnormal returns through trading stocks of their own firms (Lin and Howe, 1990; Seyhun, 1986, 1988, 1990, 1998; Rozeff and Zaman, 1998; Lakonishok and Lee, 2001; Jenter, 2005; Fidrmuc et al., 2006; Marin and Olivier, 2008; Gangopahyay et al., 2009; Jiang and Zaman, 2010). Outsiders can also profit by mimicking the insiders' transactions (Jaffe, 1974; Tavakoli et al., 2012). However, the extant literature mainly focuses on firms in highly developed capital markets where ownership is diffuse and insiders hold only a small fraction of the firm's equity. As a result, we know less about firms where insiders are also large shareholders, which could create different motives for trading. To fill this gap in the literature, we explore the link between insiders' trading activity and future stock returns. Our findings should enable us to assess whether previous results in markets where ownership is diffuse also hold in countries with more concentrated ownership. Additionally, they will allow us to assess whether investors can make profits by mimicking the trading activity of insiders with different levels of ownership.

To address these issues, we employ data from a number of countries where firms are characterised by higher ownership concentration. In particular, our dataset includes China, Hong Kong, India, Singapore, and Taiwan and spans the period from 2003:01 to 2012:05. It is well documented that, unlike the US for example, most corporations in East Asia have concentrated ownership structures (La Porta et al., 1999; Claessens et al., 2000; Faccio and Lang, 2002). With more concentrated ownership of the firm's equity, insiders have the incentive and power to take actions that benefit themselves at the expense of the firm's performance and thus at the expense of outside shareholders (see, e.g., Fama and Jensen, 1985). On the other hand, more concentrated ownership in the hands of insiders can ameliorate the agency conflict between managers and shareholders. Specifically, as their 
stakes in the company increase, managers pay a larger share of the costs of deviation from value maximisation and therefore they are less likely to squander corporate wealth (Jensen and Meckling, 1976). Hence, it could be argued that the trading activity of insiders with high levels of ownership, such as the ones considered in our paper, may not always be driven by the pursuit of profit based on private information but it could also be associated with other motives. For instance, they might want to support the price of their own firm's shares, which may be used in other dealings as collateral, through buying transactions or they could be making a market for their firms' shares if traded in relatively thin markets (Firth et al., 2011). Alternatively, insiders' buying activity may serve as a signal of the quality of their company to outside shareholders (Leland and Pyle, 1977). An important implication of the above and also one of the motivations of our paper is that outside investors who try to mimic the trading behaviour of insiders with high fractions of ownership may not always manage to gain profits compared to investors in the US and other highly developed markets.

Our contributions to the literature in relation to the above issues are as follows. First, although we confirm much of the previous literature by finding a significantly negative relation between the selling activity of insiders and future stock returns (e.g., Seyhun, 1986), we show that the relation between their buying activity and future stock returns is also negative. This is a new finding in East Asian markets which is in sharp contrast to studies which focus on the US or on European markets (e.g., Lin and Howe, 1990; Gregory et al., 1997; Lakonishok and Lee, 2001) and suggests that there could be other motives when insiders acquire shares. In particular, this could be explained by the high level of ownership which typically characterises the firms in the countries of our sample. To investigate the issue, we split directors into two groups, (i) the top directors comprised of the CEO and the Chairman of the firm, and (ii) the rest of the directors. Interestingly, we indeed find that the negative relationship between stock returns and buying activity is related to top managent and 
we further demonstrate that top managers with higher ownership levels drive this result. Therefore, our paper posits the view that the buying activity of insiders in firms where they possess high levels of ownership can be associated with reasons other than timing the market in order to realise profits. For example, they could aim at supporting their own firm's share price or they could make a market for the shares of their firm. Within this context, our study offers fresh empirical evidence on an important issue while at the same time it complements a smaller body of literature which focuses on firms characterised by concentrated ownership levels (e.g., Wong et al., 2000; Firth et al., 2011).

Second, we provide results of economic value which are in line with our statistical analysis and have important implications for outside investors. Specifically, we show that a trading strategy that focuses solely on purchases made by top directors with low ownership levels yields high positive returns. However, our analysis reveals that a similar strategy which follows the buying activity of insiders with high ownership levels generates negative returns. We additionally show that the difference between risk-adjusted returns based on the Sharpe ratios obtained from the two different strategies, is statistically significant. For a more comprehensive analysis, we calculate the corresponding risk-adjusted portfolio returns (alphas) for the CAPM, Fama-French three-factor model, and Carhart four-factor model and our results remain unaltered. In light of this interesting finding, our paper suggests that investors who try to mimic the buying activity of insiders should be cautious as insiders may have different motives depending on their level of ownership. Finally, we additionally provide a series of robustness checks in relation to sample selectivity, unobserved institutional characteristics and alternative explanations, and our main conclusions remain unaffected.

Overall, this paper provides some fresh evidence and empirically demonstrates that the trading activity of insiders is not always associated with the same motives as these can be 
explained by the different levels of ownership and do not aim at making profits in all instances. Consequently, outside investors who want to time the market and make a profit for themselves, should be aware of these issues when formulating trading strategies.

The remainder of the paper is organised as follows. Section 2 describes the data employed in this study and offers some summary statistics, Section 3 provides the methodological approach and discusses the empirical findings, and Section 4 concludes the study.

\section{Data}

\subsection{Regulatory background}

Our study employs insider trading data derived from the stock markets of China, Hong Kong, India, Singapore and Taiwan. As stated from China Securities Regulatory Commission, a director or senior management officer of a listed company shall notify the listed company and the listed company shall announce on the website of the Stock Exchange any change of the shares in the company held by such investor within two days of actual occurrence of the change. The announcement shall include the number of shares held before and after the change as well as the date and the price at which they were acquired or disposed. In Hong Kong, directors are also required to report changes in shareholding interests to the Stock Exchange of Hong Kong within five working days (see, e.g., Cheuk et al., 2006). Similar disclosure requirements are imposed by the respective securities commissions in the remaining markets of our sample. Therefore, these regulations allow us to investigate whether outside investors can formulate profitable trading strategies based on the trading activity of insiders.

\subsection{Data description}


Insider trading data in this paper are compiled from DataStream (Thomson Reuters), Asian Insider Transaction/Holdings Feed, covering the period from January 2003 to May 2012. This period covers the recent financial crisis that affected markets throughout the world. The database contains records of more than 400,000 insider transactions of which more than 140,000 are classified as direct transactions in 7,203 firms (issuers) that trade on the stock markets of China, Hong Kong, India, Singapore and Taiwan. The data are aggregated to the monthly frequency and in line with the standard approach in the literature we focus on openmarket purchases and sales of shares (see, e.g., Lakonishok and Lee, 2001; Iqbal and Shetty, 2002; Cohen et al., 2012). Moreover, following Conrad and Kaul (1993) and Lakonishok and Lee (2001), we exclude share grants, transfers, option exercises, non-common shares, depository receipts, closed-end funds, real estate investment trusts, convertible debt, exchange notes and stock options from our analysis. Finally, in line with prior studies (e.g., McMillan et al., 2014), firms with less than 12 (not necessarily consecutive) months of transactions are also excluded.

We merge our insider transactions data with financial firm-level data from DataStream using CUSIP. Firms are excluded from our sample if they do not have share price information. Of the 7,203 firms in our original dataset, 6,551 firms have enough information regarding valid matching CUSIP codes and firm sizes over the sample period. Furthermore, to filter out potential recording errors embedded in DataStream we follow Ince and Porter (2006) and Andriosopoulos et al. (2014) and we apply a similar screening procedure to stock returns. ${ }^{1}$ Monthly stock returns are computed as $R_{i, t}=\log \left(P_{i, t}\right)-\log \left(P_{i, t-1}\right)$, where $P_{i, t}$ denotes the closing stock price of firm $i$ at time $t$.

The asset pricing literature finds significant cross-sectional predictability in stock

\footnotetext{
${ }^{1}$ Returns for months $t$ and $t-1$ are set to missing if $\left(1+R_{t}\right)\left(1+R_{t-1}\right)-1<50 \%$, where $R_{t}$ is the return for month $t$, and at least one of the two returns is greater than $300 \%$ (see also Lee, 2010).
} 
returns based on firm characteristics including beta, dividend yield, price-earnings ratio, and book-to-market ratio which are correlated with a firm's subsequent stock returns (see, e.g., Litzenberger and Ramaswamy, 1982; Bernard and Thomas, 1990; Fama and French, 1992). Therefore, in addition to insider trading activity we also include the dividend yield, size, book-to-market ratio, the company's beta, and the debt-to-total assets ratio in our analysis. Given that recent evidence suggests that U.S. stock returns have significant explanatory power for non-U.S. market returns (see, Rapach et al., 2013), we also control for the returns on the S\&P 500 index. This allows us to examine whether the insider trading information has predictive power over and above information that would be publicly available. Finally, we also account for the potential impact of the recent global financial crisis by incorporating into our model the Crisis dummy variable that takes the value of one from September 2007 onwards and zero otherwise.

\subsection{Summary statistics}

Table 1 shows the number of firms with insider trading and the number and volume of insider transactions across all five countries. The ratio of the number of insider transaction purchases to insider sales ranges from 2.57 for Taiwan to 8.11 for Singapore for all directors, while the range of this ratio for the top directors is slightly tighter across the countries. With respect to the ratio of the volume of insider transaction purchases to insider sales, this ranges from just 2.78 for Hong Kong to 22.86 for China, while the range of the same ratio for top directors is slightly wider. These results are in line with other studies (Cheuk et al., 2006; Firth et al., 2011) and show that both the number and volume of insider purchases in these countries are much greater than their respective insider sales as compared to US transactions where insiders are, on average, sellers (Seyhun, 1998; Jeng et al., 2003; Ravina and Sapienza, 2010; Tavakoli et al., 2012). One possible explanation for this discrepancy is that, unlike the U.S., 
equity-based remuneration is not as popular in East Asia and this could lead to relatively less insider selling for portfolio rebalancing following stock or option grants.

[Insert Table 1 around here]

In general, our data sample suggests that directors are heavy traders both in terms of number of transactions and volume of trading and buy far more than they sell. Directors in East Asia may sell relatively less frequently for a number of reasons. These could include making a market for their firms' share with the aim of maintaining their values used as collaterals in other financial dealings, to provide liquidity for their firm's shares or to send a positive signal about the future prospects of their firm to the market. However, if directors do sell, apart from personal liquidity needs, this could convey a negative signal regarding the future performance of their companies to the market.

\section{Methodology and Results}

\subsection{Stock returns and insiders' trading activity: predictive regressions}

Initially, we employ regressions of one-month-ahead stock returns on the directors' trading activity. There is an abundance of evidence in the extant literature which suggests that insiders can earn abnormal returns through buying (selling) shares of their own firm (e.g., Seyhun, 1990, 1998; Lakonishok and Lee, 2001). Based on this evidence we expect the relation between one-month-ahead stock returns and directors' buying (selling) activity to be positive (negative). To better capture trading activity (either buying or selling), we consider the volume of shares and we run pooled regressions with standard errors clustered both at the firm and country level. ${ }^{2}$ Specifically, we estimate the following predictive regression: ${ }^{3}$

\footnotetext{
${ }^{2}$ Our results are robust to the use of dollar weighted insiders' buying (selling) activity.
} 


$$
R_{i, t+1}=a+\text { bInsideTrade } \text { I }_{t,}+\gamma X_{i, t}+M_{t}+C_{i}+\varepsilon_{i, t}
$$

where $R_{i, t}$ denotes the return on stock $i$ at time $t$, and InsideTrade $e_{i, t}$ is the insiders' trading activity, which could be either buys or sells. $X_{i, t}$ denotes a vector of controlling variables that have been shown to have predictive power for stock returns, namely size, book-to-market ratio, dividend yield, firm's riskiness as measured by its beta, and the return on the S\&P 500 index. The model also includes month dummies, $M_{t}$, to capture time effects common to all firms, as well as country specific fixed effects, $C_{i}$, to control for unobserved country heterogeneity. Finally, $\varepsilon_{i, t}$ is a stochastic error term. The null hypothesis of no predictability, in terms of insiders' activity, is that $b$ is zero in equation (1), while the alternative hypothesis of predictability predicates that $b \neq 0$. The results are presented in Table 2 .

[Insert Table 2 around here]

Columns 1-3 of Table 2 illustrate that both buying and selling activity are strong predictors of future stock returns. In line with much of the previous literature, we find that selling activity predicts lower future returns (significant at the $1 \%$ level, see column 3 ). On the other hand, the relation between buying activity and future returns is also negative suggesting that insiders on average incur a loss throughout the sample period which amounts to 1.3 basis points for every million of shares bought. This result is in sharp contrast to previous studies which suggest that insiders should be able to earn positive profits when using their informational advantage. This is an interesting finding in East Asian markets which leads to the question of why the relation between buying activity and future returns follows a different pattern compared to, for instance, the US market. To further explore this issue and to identify what drives this result, we decompose our sample into CEOs and Chairs,

\footnotetext{
${ }^{3}$ A number of studies in the return predictability literature focus on the spurious evidence of predictability which can arise as a result of highly persistent predictive variables (see, inter alia, Nelson and Kim, 1993; Stambaugh, 1999; Amihud and Hurvich, 2004; Philips and Lee, 2013). However, our inferences are not affected by such concerns given that the predictive variables employed in our paper are far from being persistent.
} 
and other directors and re-examine the aforementioned relation. The results are presented in Table 3.

[Insert Table 3 around here]

As can be seen from this table, the negative relation between buying activity and future returns in East Asian countries is associated with the top directors (i.e. CEOs and Chairs). Specifically, both CEOs and Chairs have a negative and statistically significant coefficient, whereas the rest of the directors' buying activity predicts positive future returns. Furthermore, we find that the difference in the coefficients on buying activity between the CEOs (Chairs) and the rest of the directors is 24 (48) basis points and statistically significant at the $1 \%$ level. As shown in column 2, these results are robust when we also control for the directors' selling activity in the model. ${ }^{4}$ Based on the above findings, it appears that there is a distinctive difference between top management and the rest of directors regarding their ability to time the market. This is particularly interesting given that top directors should have access to at least the same information as the rest of the directors and hence, they should be able to exploit it for their own benefit. Therefore, we posit the view that there might be other reasons behind their buying activity which are not related to market timing. For instance, a plausible explanation could be that top directors in East Asian markets might buy their own firms' shares to support their price with the aim to achieve beneficial results in the long-run or to make a market for their firms' shares. This could indeed be the case given that compared to firms in the US for example, firms incorporated in the countries included in our sample have a less diffuse ownership and in some cases they can even be family owned.

\footnotetext{
${ }^{4}$ As is evident from Table 1, Hong Kong comprises a large fraction of our sample. The context here is relevant to the study of Brochet (2017) which involves a similar issue. Following Brochet (2017), we conduct an empirical analysis excluding Hong Kong from our sample and we find that the negative relationship between the buying activity of top directors and stock returns remains robust to this exclusion. Therefore, our main inferences are not driven by Hong Kong.
} 
To further investigate this issue and in line with our proposition, we consider the top directors' ownership levels and explore whether these indeed play an important role in this context conditioned on the number of shares acquired. The relevant model is expressed as:

$$
R_{i, t+1}=a+b_{1} \operatorname{Top}_{i, t}+b_{2} O w n_{i, t}+b_{3} \text { Top }_{i, t} * O w n_{i, t}+\gamma X_{i, t}+M_{t}+C_{i}+\varepsilon_{i, t},
$$

where $\operatorname{Top}_{i, t}$ denotes the top directors' buying activity in firm $i$ at time $t$ and $O w n_{i, t}$ is the ownership level of the top directors in firm $i$ at time $t . X_{i, t}$ denotes the vector of control variables, while $M_{t}$ and $C_{i}$, respectively, denote month and country fixed effects, as described in equation (1). The results are tabulated in Table 4.

[Insert Table 4 around here]

Looking at column 1 in Table 4, we observe that there is a negative relation between future returns and the level of ownership conditional on the number of shares acquired. However, the corresponding interaction term is based on all buying activity from top directors and does not distinguish between different motives. For instances, given a negative firm's past market performance top directors with high ownership levels are more likely to initiate a price support purchase. Based on this notion, we estimate another interaction model to obtain the relation between the next month's returns and top directors' ownership levels conditioned on the firm's past market performance and number of shares acquired. In particular, we capture the firms' past performance using a dummy variable $\left(\right.$ Perform $\left._{t}\right)$ that takes the value of one if the return in the previous period is negative, and zero otherwise. The corresponding model can be expressed as follows:

$$
\begin{aligned}
R_{i, t+1}= & a+b_{1} \text { Top }_{i, t}+b_{2} \text { Own }_{i, t}+b_{3} \text { Top }_{i, t} * \text { Own }_{i, t}+b_{4} \text { Top }_{i, t} * \text { Perform }_{i, t}+ \\
& b_{5} \text { Own }_{i, t} * \text { Perform }_{i, t}+b_{6} \text { Top }_{i, t} * \text { Own }_{i, t} * \text { Perform }_{i, t}+\gamma X_{i, t}+M_{t}+ \\
& C_{i}+\varepsilon_{i, t},
\end{aligned}
$$


The results presented in column 2 suggest that ownership levels are negatively associated with future returns and they are also statistically significant. This finding indicates that the top directors' buying activity is not always associated with market timing. It could also be motivated by other factors such as price support which could result in insiders realising negative returns. To explore this further, we turn our attention to firms' fundamentals. Specifically, we investigate whether the reported negative relation between future returns and the level of ownership still holds under the scenario where firms' fundamentals, as captured by either the earnings growth or the dividend growth, are strengthened. If this were the case, it would imply that top managers with high ownership levels are motivated by price support so as to signal to the market that their firms are currently undervalued. To this end, we introduce $E G D_{i, t}\left(D G D_{i, t}\right)$, a dummy variable that takes the value of one if a firm's earnings growth (dividend growth) is positive in the previous quarter, and zero otherwise. Subsequently, we extend with this variable the interaction terms used in Equation (3). The corresponding results are tabulated in columns 1 and 2 of Table 5. We find that the estimated coefficients of the new interaction terms are both negative and statistically significant which is in line with the notion of price support from top directors.

[Insert Table 5 around here]

On the other hand, there might be additional factors, not necessarily mutually exclusive to price support that could determine the buying activity of top directors with high ownership levels and explain our findings. Such factor could be the thin trading of shares which is linked to higher price volatility (see, Pagano, 1989) and could result in a higher cost of equity (Botosan and Plumlee, 2002). To explore this aspect in our analysis, we construct a dummy variable $\left(T V D_{i, t}\right)$ that takes the value of one if the trading volume of a firm is lower 
than the average trading volume of the previous twelve months and zero otherwise. ${ }^{5}$ Subsequently, we re-estimate Equation (3) interacted with this variable. The results are tabulated in column 3 of Table 5. We find that the coefficient of interest is statistically insignificant. This finding implies that the motives behind the buying activity of top directors within our sample are more likely to be linked to price support rather than to the thinness of the market.

\subsection{Portfolio returns}

In this section we analyse the returns of two portfolios formed based on top directors with high ownership levels and top directors with low ownership levels in the company. This analysis complements our previous findings and provides a further robustness check, whereas it is also of interest to investors. Specifically, we consider an investor who goes long on firms with negative past market performance when their top directors have high ownership levels and show buying activity. When there is no buying activity the investor goes long on the riskfree asset. We also consider a second investor under the same setup with the only difference being that she tracks the buying activity of top directors with low ownership levels. We report only the value-weighted results in this study. ${ }^{6}$

Apart from reporting the raw returns, we also employ Sharpe ratios and further adjust the portfolio returns on the basis of common risk factors. Fama and French (1996) show that their three-factor model can explain most commonly documented Capital Asset Pricing Model (CAPM) anomalies except for the momentum anomaly. For each portfolio $i$, the abnormal return in excess of the Fama-French three-factor model is captured by the intercept in the following regression model:

\footnotetext{
${ }^{5}$ Results are similar if the trading volume of the previous month is used instead.

${ }^{6} \mathrm{We}$ have also run our tests based on equally-weighted portfolio returns and our results are qualitatively similar.
} 


$$
R_{i, t}-R_{f, t}=a_{i}+b_{i}\left(R_{m, t}-R_{f, t}\right)+s_{i} S M B_{t}+h_{i} H M L_{t}+\varepsilon_{i, t}
$$

where $R_{i, t}-R_{f, t}$ is the return on portfolio $i$ in excess of the risk-free rate in month $t, R_{m, t}$ $R_{f, t}$ is the excess return on the market value-weighted portfolio, SMB is the return differential between portfolios of small and large stocks, and HML is the spread in the returns between portfolios of value (high book-to-market ratio) and growth (low book-to-market ratio) stocks. Thus, the factors SMB and HML represent the size and value premia, respectively.

Since the Fama-French three-factor model does not capture the momentum effect, Carhart (1997) suggests adding a fourth factor (WML) that is based on the returns of a diversified portfolio going long on recent winners and short on recent losers which captures momentum in the three-factor model. For each portfolio $i$, the abnormal return in excess of the four-factor model is captured by the intercept in the following regression:

$$
R_{i, t}-R_{f, t}=a_{i}+b_{i}\left(R_{m, t}-R_{f, t}\right)+s_{i} S M B_{t}+h_{i} H M L_{t}+w_{i} W M L_{t}+\varepsilon_{i, t},
$$

where $R_{i, t}-R_{f, t}$ is the return on portfolio $i$ in excess of the risk-free rate in month $t, R_{m, t}$ $R_{f, t}$ is the excess return on the market value-weighted portfolio, SMB is the size factor, HML is the value factor, and WML is the momentum factor.

The corresponding results in Table 6 show that a trading strategy focusing solely on purchases made by top directors with low ownership levels earns large positive returns, while a strategy that follows the purchases of top directors with high ownership levels does not. For example, the low ownership portfolio earns $1.96 \%$ per month, which combined with a standard deviation of $13.24 \%$ leads to a Sharpe ratio of 0.147 , whereas the high ownership portfolio generates $-0.88 \%$ per month and yields a Sharpe ratio of $-0.122 \%$. 
Following Ledoit and Wolf (2008), we also test the null hypothesis that the corresponding Sharpe ratios of high and low ownership portfolios are equal by considering the difference between Sharpe ratios:

$$
\Delta S R=S R_{\text {low }}-S R_{\text {high }}
$$

where $S R_{\text {low }}$ denotes the Sharpe ratio of the low ownership portfolio and $S R_{\text {high }}$ denotes the Sharpe ratio of the high ownership portfolio. The test statistic by Ledoit and Wolf (2008) uses heteroscedasticity and autocorrelation consistent (HAC) standard errors and is asymptotically distributed as a standard normal random variable.

The estimated Ledoit and Wolf (2008) test statistic tabulated in Table 6, with a twosided $p$-value of 0.001 , suggests that the Sharpe ratio produced from the low ownership portfolio is statistically different to the one from the high ownership portfolio. This finding indicates that the risk-adjusted return generated by investing in firms with negative past market performance when their top directors with low levels of ownership show buying activity, is significantly higher than the corresponding risk-adjusted return produced by investing in firms where the top directors with high ownership are buying shares. The riskadjusted portfolio returns (alphas) for the CAPM, Fama-French three-factor model, and Carhart four-factor model reveal a similar pattern and corroborate the previous results. In this case, a portfolio strategy that goes long on low ownership buys and short on high ownership buys earns a four-factor alpha of 250 basis points per month $(t=2.25)$, or over $30 \%$ per year.

[Insert Table 6 around here]

Overall, our findings in this section indicate that top directors do not always act with the aim to time the market, but there could be alternative reasons such as price support that motivates them to buy shares of their own firm, especially when they have a high stake in the 
firm (i.e. a high ownership level). Therefore, investors in these markets should consider the ownership level of top directors when trying to mimic their trading activity.

\section{Robustness checks}

This section provides further empirical evidence by means of additional robustness checks in relation to issues of sample selectivity and institutional characteristics. ${ }^{7}$

\subsection{Sample selectivity checks}

One of the main findings of this study is the negative relation between insiders' buying activity and future stock returns. As mentioned above, this is a new finding in East Asian markets which is in sharp contrast to studies that focus on the US or on European markets. One factor that could drive this result is the recent global financial crisis. If the decline in stock market prices that occurred during this period was coupled by increased insider purchasing activity, then the negative relation between insider trading and future stock returns could be the outcome of this subperiod.

To examine such sample selectivity and alleviate any concern, we re-estimate column 3 of Table 2 by incorporating the interaction of InsideTradeBuy and InsideTradeSell with the recent global financial crisis. For a more comprehensive analysis, we divide the crisis into two periods. The first period spans September 2007 (the Northern Rock bank run) to August 2008 and the second period spans September 2008 (the Lehman Brothers collapse) to January 2009. We then interact the corresponding dummy variables with InsiderTradeBuy (InsiderTradeSell). The results, reported in Panel A of Table 7, suggest that our previous findings remain robust to the inclusion of these interaction terms and the relation between the

\footnotetext{
${ }^{7}$ We thank an anonymous reviewer for suggesting these robustness checks.
} 
buying activity of directors and future stock returns is still negative and significant during both calm and turmoil periods.

As an additional robustness check regarding sample selectivity, we explore whether the negative relation between insiders' buying activity and future stock returns is driven by large or small firms. To address this issue, we initially classify firms that belong to the lower tertile (in terms of size) of our sample as small, while those that belong to the top tertile are classified as large. We then re-estimate column 3 of Table 2 with respect to both small and large firms. The results are presented in Panel B of Table 7. Consistent with our previous results, we find a negative and significant relation (at the $1 \%$ level) between the buying activity and future returns with respect to both types of firms. This suggests that our previous findings are not driven by firm size.

[Insert Table 7 around here]

\subsection{Other checks}

As shown in our main analysis, the negative relation between the insiders' buying activity and future stock returns is explained by the trading activity of top directors with high ownership levels. However, each of the five countries studied may reflect differences or variation in their institutional characteristics which are not related to high ownership levels and could produce a similar result. To address this concern, we re-estimate column 2 of Table 4 including month-country fixed effects to capture any time varying institutional characteristics. The corresponding results are tabulated in Table 8 and indicate that our previous findings remain robust to this specification.

[Insert Table 8 around here] 
Moreover, we explore another angle which might shed more light on the motives of insider trading and is related to blackout periods. Blackout periods, during which insiders have an even greater informational advantage, constitute a mechanism that firms and/or regulators use to restrain informed insider trading (Bettis et al., 2000). Within this context, we aim to investigate whether insiders exploit the additional information they possess to make a profit. To this end, we assume that a blackout period is enforced in the month preceding earnings announcements and we create a relevant dummy (Blackout) that captures this. ${ }^{8}$ Subsequently, we re-estimate Equations (1) and (3) for the different periods (i.e. blackout vs non-blackout). The corresponding results are tabulated in Table 9.

\section{[Insert Table 9 around here]}

Looking at column 1, the coefficients on the interaction terms of CEO and Chair with the Blackout dummy variable are positive and statistically significant (at the $10 \%$ and $1 \%$ level, respectively), whereas the coefficient on the interaction term between the rest of the directors and the blackout dummy is statistically insignificant. These results indicate that the buying activity of top directors is more profitable during blackout periods relative to nonblackout periods, while the rest of directors experience the same profitability over the full period. Therefore, the purchases of top directors in the month prior to earnings announcements are more likely to be information driven rather than motivated by other considerations. However, when we condition top directors' buying activity on their ownership levels and firm's past market performance the coefficient of interest is negative and highly significant (see column 2). This finding suggests that top directors with high stakes in the firm are more likely to initiate a price support purchase rather than time the market when their firm faces a declining share price.

\footnotetext{
${ }^{8}$ In our sample, the average percentage of trades in the month before earnings announcements is $11.6 \%$.
} 


\section{Conclusion}

This paper investigates the relation between stock returns and the trading activity of insiders in firms with high ownership concentration. To this end, we employ data from countries with this characteristic in firm ownership which include China, Hong Kong, India, Singapore, and Taiwan and cover the period from 2003:01 to 2012:05. Our paper complements the extant literature which mainly focuses on firms in highly developed markets where ownership is diffuse, by providing fresh empirical evidence based on firms where insiders hold a large fraction of the firm's equity and their trading activity might be associated with different motives. The findings in this paper have important implications for two reasons. First, they enable us to assess whether previous findings in markets where ownership is difusse also hold in markets with high ownership concentration. Hence, they shed more light on how future stock returns are affected by the different levels of ownership. Second, they allow us to examine whether outside investors who mimic the trading activity of insiders can make profits for themselves. In connection to the above issues, we contribute to the literature in the following ways.

First, although we corroborate the existing literature by finding a significantly negative relation between the selling activity of insiders and future stock returns (e.g., Seyhun, 1986), our results reveal that the relation between the buying activity of insiders and future stock returns is also negative. This is an interesting new finding in East Asian markets which is in sharp contrast to studies which focus on the US or on European markets (e.g., Lin and Howe, 1990; Gregory et al., 1997; Lakonishok and Lee, 2001) and points to the direction that insiders may not always be driven by profit making motives when they purchase shares. To explore the issue, we group insiders into top directors and the rest of the directors and we show that the negative relation between the insiders' buying activity and future stock returns is associated with the top directors. Furthermore, we demonstrate that top directors with 
higher ownership levels drive this result. Consequently, our findings indicate that insiders who possess high levels of ownership can have different motives when they acquire their firm's shares which are not always related to market timing in order to realise profits. For instance, their goal could be to support their own firm's share price, or they might want to make a market for their firm's shares.

Second, we show that a trading strategy which focuses solely on purchases made by top directors with low ownership levels leads to high positive returns. However, we also find that a similar strategy which tracks the buying activity of insiders with high ownership levels generates negative returns. Additionally, we find that the difference between risk-adjusted returns based on the Sharpe ratios obtained from the two different strategies, is also statistically significant. For a more comprehensive analysis, we compute the corresponding risk-adjusted portfolio returns (alphas) for the CAPM, Fama-French three-factor model, and Carhart four-factor model and our results remain unaffected. Therefore, our findings based on economic value are consistent with our statistical analysis and further strengthen our main conclusions. Finally, we additionally conduct a series of robustness checks which are related to sample selectivity and institutional characteristics, and our main conclusions do not change.

Overall, this paper empirically demonstrates that the trading activity of insiders is not always aimed at realising profits and can be explained by their different levels of ownership. Hence, outside investors who mimic the buying activity of insiders should be aware of these issues and proceed with caution when they form trading strategies in order to time the market. 


\section{References}

Amihud, Y., Hurvich, C.M., 2004. Predictive regressions: A reduced-bias estimation method. Journal of Financial and Quantitative Analysis, 39, 813-841.

Andriosopoulos, D., Chronopoulos, D.K., Papadimitriou, F.I., 2014. Can the information content of share repurchases improve the accuracy of equity premium predictions? Journal of Empirical Finance 26, 96-111.

Bernard, V., Thomas, J., 1990. Evidence that stock prices do not fully reflect the implications of current earnings for future earnings. Journal of Accounting and Economics 13, 305-340.

Bettis, J.C., Coles, J., Lemmon, M.L., 2000. Corporate policies restricting trading by insiders. Journal of Financial Economics 57, 191-220.

Botosan, C.A., Plumlee, M.A., 2002. A re-examination of disclosure level and the expected cost of equity capital. Journal of Accounting Research 40, 21-40.

Brochet, F., 2017. Aggregate insider trading and market returns: The role of transparency. Working Paper, Boston University.

Carhart, M., 1997. On persistence in mutual fund performance. Journal of Finance 52, 57-82.

Cheuk, M.Y., Fan, D.K., Sob, R.W., 2006. Insider trading in Hong Kong: Some stylized facts. Pacific-Basin Finance Journal 14, 73-90.

Claessens, S., Djankov, S., Lang, L.H.P., 2000. The separation of ownership and control in East Asian Corporations. Journal of Financial Economics 58, 81-112.

Cohen, L., Malloy, C., Pomorski, L., 2012. Decoding inside information. Journal of Finance 67, 1009-1043.

Cheuk, M., Fan, D.K., So, R..W., 2006. Insider trading in Hong Kong: Some stylized facts, Pacific Basin Finance Journal 14, 73-90.

Conrad, J., Kaul, G., 1993. Long-term market overreaction or biases in computed returns? Journal of Finance 48, 39-63.

Faccio, M., Lang, L.H.P., 2002. The ultimate ownership of western European corporations. Journal of Financial Economics 65, 365-395.

Fama, E.F., French, K.R., 1992. The cross-section of expected stock returns. Journal of Finance 47, 427-465.

Fama, E.F., French, K.R., 1996. Multifactor explanations of asset-pricing anomalies. Journal of Finance 51, 55-84.

Fama, E.F., Jensen, M.C., 1985. Organizational forms and investment decisions. Journal of Financial Economics 14, 101-119.

Fidrmuc, J., Goergen, M., Renneboog, L., 2006. Insider trading, news releases and ownership concentration. Journal of Finance 61, 2931-2973.

Firth, M., Leung, T.Y., Rui, O.M., 2011. Insider trading in Hong Kong: Tests of stock returns and trading frequency. Review of Pacific Basin Financial Markets and Policies 14, $505-533$. 
Gangopahyay, P., Yook, K.C., Sarwar, G., 2009. Profitability of insider trades in extremely volatile markets: Evidence from the stock market crash and recovery of 2000-2003. Quarterly Journal of Finance and Accounting 48, 45-61.

Gregory, A., Matatko, J., Tonks, I., 1997. Detecting information from directors' trades: Signal definition and variable size effects. Journal of Business Finance and Accounting 24, 309-342.

Ince, O.S., Porter, R.B., 2006. Individual equity return data from Thompson Datastream: Handle with care! Journal of Financial Research 29, 463-479.

Iqbal, Z., Shetty, S., 2002. An investigation of causality between insider trading transactions and stock returns. The Quarterly Review of Economics and Finance 42, 41-57.

Jaffe, J.F., 1974. Special information and insider trading. Journal of Business 47, 410-428.

Jeng, L.A., Metrick, A., Zeckhauser, R., 2003. Estimating the returns to insider trading: A performance-evaluation perspective. Review of Economics and Statistics 85, 453471.

Jensen, M.C., Meckling, W.H., 1976. Theory of the firm: Managerial behavior, agency costs and ownership structure. Journal of Financial Economics 3, 305-360.

Jenter, D., 2005. Market timing and managerial portfolio decisions. Journal of Finance 60, 1903-1949.

Jiang, X., Zaman, M.A., 2010. Aggregate insider trading: Contrarian beliefs or superior information? Journal of Banking \& Finance 34, 1225-1236.

Lakonishok, J., Lee, I., 2001. Are insider trades informative? Review of Financial Studies 14, 79-111.

La Porta, R., Lopez-de-Silanes, F., Shleifer, A., 1999. Corporate ownership around the world. Journal of Finance 54, 471-517.

Ledoit, O., Wolf, M., 2008. Robust performance hypothesis testing with the Sharpe ratio. Journal of Empirical Finance 15, 850-859.

Lee, K., 2010. The world price of liquidity risk. Journal of Financial Economics 99, 136-161.

Leland, H.E., Pyle, D.H., 1977. Informational asymmetries, financial structure, and financial intermediation. Journal of Finance 32, 371-387.

Lin, J., Howe, J., 1990. Insider trading in the OTC Market. Journal of Finance 45, 12731284.

Litzenberger, R., Ramaswamy, K., 1982. The effects of dividends on common stock prices: Tax effects or information effects? Journal of Finance 37, 429-443.

Marin, J.M., Olivier, J.P., 2008. The dog that did not bark: Insider trading and crashes. Journal of Finance 63, 2429-2476.

McMillan, D.G., Tavakoli, M., McKnight, P.J., 2014. Insider employee stock option trading and stock prices. European Journal of Finance 20, 59-79.

Nelson, C.R., Kim, M.J., 1993. Predictable stock returns: the role of small sample bias. Journal of Finance, 48, 641-661.

Pagano, M., 1989. Endogenous market thinness and stock price volatility. Review of Economic Studies 56, 269-287. 
Philips, P.C.B., Lee, J.H., 2013. Predictive regression under various degrees of persistence and robust long-horizon regression, Journal of Econometrics, 177, 250-264.

Rapach, D.E., Strauss, J.K., Zhou, G., 2013. International stock return predictability: What is the role of the United States? Journal of Finance 68, 1633-1662.

Ravina, E., Sapienza, P., 2009. What do independent directors know? Evidence from their trading. Review of Financial Studies 23, 962-1003.

Rozeff, M.S., Zaman, M.A., 1998. Overreaction and insider trading: Evidence from growth and value portfolios. Journal of Finance 53, 701-716.

Seyhun, H.N., 1986. Insiders' profits, costs of trading, and market efficiency. Journal of Financial Economics 16, 189-212.

Seyhun, H.N., 1988. The information content of aggregate insider trading. Journal of Business 61, 1-24.

Seyhun, H.N., 1990. Do bidder managers knowingly pay too much? Journal of Business 63, 439-464.

Seyhun, H.N., 1998. Investment intelligence from insider trading. Cambridge, MA: MIT Press.

Stambaugh, R.S., 1999. Predictive regressions. Journal of Financial Economics, 54, 375-421.

Tavakoli, M., McMillan, D.G., McKnight, P.J., 2012. Insider trading and stock prices. International Review of Economics and Finance 22, 254-266. 


\section{Tables}

Table 1. Descriptive statistics

Number of insider transactions

Volume of insider transactions (millions of shares)

\begin{tabular}{|c|c|c|c|c|c|c|c|c|c|c|c|c|}
\hline \multirow[b]{2}{*}{ Country } & \multicolumn{3}{|c|}{ All directors } & \multicolumn{3}{|c|}{ Top directors } & \multicolumn{3}{|c|}{ All directors } & \multicolumn{3}{|c|}{ Top directors } \\
\hline & Purchases & Sales & $\frac{\text { Purchases }}{\text { Sales }}$ & Purchases & Sales & $\frac{\text { Purchases }}{\text { Sales }}$ & Purchases & Sales & $\frac{\text { Purchases }}{\text { Sales }}$ & Purchases & Sales & $\frac{\text { Purchases }}{\text { Sales }}$ \\
\hline China & 7672 & 1691 & 4.54 & 1756 & 299 & 5.87 & 58007 & 2538 & 22.86 & 34610 & 992 & 34.87 \\
\hline Hong Kong & 20162 & 4728 & 4.26 & 11546 & 1600 & 7.22 & 505892 & 182096 & 2.78 & 411575 & 151104 & 2.72 \\
\hline India & 9630 & 3026 & 3.18 & 3130 & 1025 & 3.05 & 4309 & 934 & 4.61 & 1864 & 351 & 5.31 \\
\hline Singapore & 9449 & 1165 & 8.11 & 4176 & 587 & 7.11 & 99264 & 29788 & 3.33 & 72513 & 15258 & 4.75 \\
\hline Taiwan & 19382 & 7541 & 2.57 & 5105 & 1787 & 2.86 & 182184 & 17330 & 10.51 & 41995 & 3491 & 12.03 \\
\hline
\end{tabular}

This table presents descriptive statistics over the full sample period (i.e. 2003:01-2012:05) for all markets under consideration. Specifically, we report both the total number and the volume of insider transactions (purchases or sales) made by all directors. We also split the sample and report the corresponding number and volume of transactions made by the top directors (i.e. comprised of the CEO and the Chairman of the firm). 
Table 2. Predictive regressions based on directors' trading activity.

\begin{tabular}{|c|c|c|c|}
\hline & (1) & (2) & (3) \\
\hline \multirow[t]{2}{*}{ InsideTrade-Buy } & $-0.013 * * *$ & & $-0.013 * * *$ \\
\hline & $(0.005)$ & & $(0.002)$ \\
\hline \multirow[t]{2}{*}{ InsideTrade-Sell } & & $-0.012 * *$ & $-0.012 * * *$ \\
\hline & & $(0.006)$ & $(0.006)$ \\
\hline \multirow[t]{2}{*}{ Size } & $-0.566 * * *$ & $-0.566 * * *$ & $-0.566^{* *}$ \\
\hline & $(0.023)$ & $(0.081)$ & $(0.081)$ \\
\hline \multirow[t]{2}{*}{$\mathrm{BM}$} & $-0.128 * * *$ & $-0.128 * * *$ & $-0.128 * * *$ \\
\hline & $(0.016)$ & $(0.031)$ & $(0.031)$ \\
\hline \multirow[t]{2}{*}{ DY } & $0.069 * * *$ & $0.069 * * *$ & $0.069 * * *$ \\
\hline & $(0.026)$ & $(0.021)$ & $(0.021)$ \\
\hline \multirow[t]{2}{*}{ Debt/TA } & $-0.017 * * *$ & $-0.017 * * *$ & $-0.017 *$ \\
\hline & $(0.001)$ & $(0.002)$ & $(0.002)$ \\
\hline \multirow[t]{2}{*}{ beta } & $1.003 * * *$ & $1.003 * * *$ & $1.003 * * *$ \\
\hline & $(0.102)$ & $(0.204)$ & $(0.204)$ \\
\hline \multirow[t]{2}{*}{ S\&P500 } & $0.274 * * *$ & $0.274 * *$ & 0.274 \\
\hline & $(0.007)$ & $(0.130)$ & $(0.130)$ \\
\hline \multirow[t]{2}{*}{ Crisis dummy } & $-1.940 * * *$ & $-1.940 * * *$ & $-1.940 * * *$ \\
\hline & $(0.051)$ & $(0.314)$ & $(0.314)$ \\
\hline Fixed effects & $\begin{array}{c}\text { Country \& } \\
\text { Month }\end{array}$ & $\begin{array}{c}\text { Country \& } \\
\text { Month }\end{array}$ & $\begin{array}{l}\text { Country \& } \\
\text { Month }\end{array}$ \\
\hline$R^{2}$ & 0.030 & 0.038 & 0.038 \\
\hline No of Obs. & 434801 & 434801 & 434801 \\
\hline
\end{tabular}

This table reports predictive regressions of stock returns using the insiders' buys and sells as predictive variables. The full sample spans the 2003:01-2012:05 period. The predictive regressions include a number of control variables: Size is the natural logarithm of the firm's market equity. BM is the book-to-market ratio of a given firm. $D Y, D e b t / T A$ and beta are, respectively, the dividend yield, debt-to-assets, and the firm's market risk for a given firm. S\&P500 is the return on the S\&P 500 index, whereas Crisis dummy is an indicator variable that takes the value of 1 from September 2007 onwards and 0 otherwise. Standard errors clustered both at firm and country-level are reported in parentheses. Asterisks *,**, and *** indicate statistical significance at the $10 \%, 5 \%$, and $1 \%$ level, respectively. 
Table 3. Predictive regressions based on the top directors' trading activity.

\begin{tabular}{lcc}
\hline & $(1)$ & $(2)$ \\
\hline CEO Buy & $-0.029 * * *$ & $-0.029^{* * *}$ \\
Chair Buy & $(0.003)$ & $(0.003)$ \\
& $-0.268^{* * *}$ & $-0.271^{* * *}$ \\
Rest Buy & $(0.038)$ & $(0.035)$ \\
& $0.218^{* * *}$ & $0.223^{* * *}$ \\
InsideTrade Sell & $(0.061)$ & $(0.057)$ \\
& & $-0.013 *$ \\
Size & & $(0.007)$ \\
& $-0.566^{* * *}$ & $-0.566^{* * *}$ \\
BM & $(0.081)$ & $(0.081)$ \\
& $-0.128 * * *$ & $-0.128 * * *$ \\
DY & $(0.031)$ & $(0.031)$ \\
& $0.069 * * *$ & $0.069^{* * *}$ \\
Debt/TA & $(0.021)$ & $(0.021)$ \\
beta & $-0.017 * * *$ & $-0.017 * * *$ \\
& $(0.002)$ & $(0.002)$ \\
S\&P500 & $1.003 * * *$ & $1.003^{* * *}$ \\
Crisis dummy & $(0.204)$ & $(0.204)$ \\
& $0.274 * *$ & $0.274 * *$ \\
Fixed effects & $(0.130)$ & $(0.130)$ \\
& $-1.940^{* * *}$ & $-1.940 * * *$ \\
No of Obs. & $(0.314)$ & $(0.314)$ \\
\hline
\end{tabular}

This table reports predictive regressions of stock returns using top directors' buys as a predictive variable. The full sample spans the 2003:01-2012:05 period. The predictive regressions include a number of control variables: Rest Buy denotes purchases by the rest of the directors (insiders). Size is the natural logarithm of the firm's market equity. BM is the book-to-market of a given firm. DY, Debt/TA, and beta are, respectively, the dividend yield, debt-to-assets, and the firm's market risk for a given firm. $S \& P 500$ is the return on the S\&P 500 index, whereas Crisis dummy is an indicator variable that takes the value of 1 from September 2007 onwards and 0 otherwise. Standard errors clustered both at the firm and country-level are reported in parentheses. Asterisks *, **, and *** indicate statistical significance at the 10\%, 5\%, and $1 \%$ level, respectively. 
Table 4. Predictive regressions conditioned on top directors' ownership levels.

\begin{tabular}{|c|c|c|}
\hline & (1) & (2) \\
\hline \multirow[t]{2}{*}{ Top } & 0.081 & -0.084 \\
\hline & $(0.055)$ & $(0.169)$ \\
\hline \multirow[t]{2}{*}{ Own } & -0.777 & -1.321 \\
\hline & $(1.116)$ & $(1.518)$ \\
\hline \multirow[t]{2}{*}{ Perform } & & $-0.878 * *$ \\
\hline & & $(0.375)$ \\
\hline \multirow[t]{2}{*}{ Top * Own } & $-0.435 * *$ & 0.274 \\
\hline & $(0.219)$ & $(0.728)$ \\
\hline \multirow[t]{2}{*}{ Top * Perform } & & 1.399 \\
\hline & & $(1.019)$ \\
\hline \multirow[t]{2}{*}{ Own * Perform } & & 1.109 \\
\hline & & $(0.928)$ \\
\hline \multirow[t]{2}{*}{ Top * Own * Perform } & & $-2.699 * *$ \\
\hline & & $(1.166)$ \\
\hline \multirow[t]{2}{*}{ Size } & $-0.514 * * *$ & $-0.523 * * *$ \\
\hline & $(0.141)$ & $(0.137)$ \\
\hline \multirow[t]{2}{*}{$\mathrm{BM}$} & $-0.154 *$ & $-0.156^{*}$ \\
\hline & $(0.086)$ & $(0.087)$ \\
\hline \multirow[t]{2}{*}{ DY } & $0.166 * *$ & $0.170 * * *$ \\
\hline & $(0.077)$ & $(0.076)$ \\
\hline \multirow[t]{2}{*}{ Debt/TA } & -0.008 & -0.007 \\
\hline & $(0.015)$ & $(0.016)$ \\
\hline \multirow[t]{2}{*}{ beta } & -0.193 & -0.144 \\
\hline & $(0.510)$ & $(0.488)$ \\
\hline \multirow[t]{2}{*}{ S\&P500 } & $0.329 * * *$ & $0.320 * * *$ \\
\hline & $(0.089)$ & $(0.090)$ \\
\hline \multirow[t]{2}{*}{ Crisis dummy } & $-5.039 * * *$ & $-5.014 * * *$ \\
\hline & $(1.825)$ & $(1.779)$ \\
\hline \multirow[t]{2}{*}{ Fixed effects } & Country \& & Country \& \\
\hline & Month & Month \\
\hline$R^{2}$ & 0.070 & 0.071 \\
\hline No of Obs. & 13989 & 13989 \\
\hline
\end{tabular}

This table reports predictive regressions of stock returns using top directors' purchases as a predictive variable conditioned on their ownership level $(O w n)$ and firm's past performance (Perform). The full sample spans the 2003:01-2012:05 period. The predictive regressions include a number of control variables: Size, BM, DY, Debt/TA, beta, S\&P500, and Crisis dummy (see appendix for variable definitions). Standard errors clustered both at the firm and country-level are reported in parentheses. Asterisks ***, and *** indicate statistical significance at the $10 \%, 5 \%$, and $1 \%$ level, respectively. 
Table 5. Exploring the motives behind top directors' buying activity

\begin{tabular}{|c|c|c|c|}
\hline & & & Thin trading \\
\hline & (1) & (2) & (3) \\
\hline Top* Own * Perform & $\begin{array}{c}-2.361 * * * \\
(0.307)\end{array}$ & $\begin{array}{c}-4.911 * * \\
(2.198)\end{array}$ & $\begin{array}{c}-7.734 * * * \\
(0.758)\end{array}$ \\
\hline Top * Own * Perform * EGD & $\begin{array}{c}-8.739 * * * \\
(0.763)\end{array}$ & & \\
\hline Top* Own * Perform * DGD & & $\begin{array}{c}-46.114 * * * \\
(10.772)\end{array}$ & \\
\hline Top * Own * Perform * TVD & & & $\begin{array}{l}-4.795 \\
(3.210) \\
\end{array}$ \\
\hline Controls & Yes & Yes & Yes \\
\hline Fixed effects & $\begin{array}{c}\text { Country \& } \\
\text { Month }\end{array}$ & $\begin{array}{l}\text { Country \& } \\
\text { Month }\end{array}$ & $\begin{array}{l}\text { Country \& } \\
\text { Month }\end{array}$ \\
\hline$R^{2}$ & 0.072 & 0.072 & 0.076 \\
\hline No of Obs. & 13989 & 13989 & 13989 \\
\hline $\begin{array}{l}\text { Column } 1 \text { reports estimates of } \\
\text { value of } 1 \text { if a firm's earnings } \\
\text { reports estimates of Equation ( } \\
\text { firm's dividend growth is pos } \\
\text { estimates of Equation (3) exte } \\
\text { trading volume of a firm is lor } \\
\text { and } 0 \text { otherwise. Controls inc } \\
S \& P 500 \text { and Crisis dummy (se } \\
\text { the firm and country-level are } \\
\text { significance at the } 10 \%, 5 \% \text {, an }\end{array}$ & $\begin{array}{l}\text { (3) extend } \\
\text { positive in tl } \\
\text { ed by DGD, } \\
\text { he previous } \\
\text { TVD, a dur } \\
\text { the average } \\
\text { er order ter } \\
x \text { for variabl } \\
\text { in parenthes }\end{array}$ & $\begin{array}{l}\mathrm{SD} \text {, a dummy } \\
\text { is quarter, an } \\
\text { variable that } \\
\text { and } 0 \text { other } \\
\text { able that tak } \\
\text { lume of the } \\
\text { ell as Size, b } \\
\text { ons). Standarc } \\
\text { sks *,**, anc }\end{array}$ & $\begin{array}{l}\text { e that takes the } \\
\text { rwise. Column } 2 \\
\text { le value of } 1 \text { if a } \\
\text { lumn } 3 \text { reports } \\
\text { alue of } 1 \text { if the } \\
\text { twelve months } \\
\text { Debt/TA, beta, } \\
\text { clustered both at } \\
\text { dicate statistical }\end{array}$ \\
\hline
\end{tabular}


Table 6. Portfolio performance comparison between top directors with high and top directors with low ownership levels.

\begin{tabular}{|c|c|c|c|c|}
\hline & $\begin{array}{c}\text { High } \\
\text { Ownership }\end{array}$ & $\begin{array}{c}\text { Low } \\
\text { Ownership }\end{array}$ & $\begin{array}{c}\text { L/S } \\
\text { Ownership }\end{array}$ & $\begin{array}{l}\text { Ledoit \& Wolf } \\
\text { (2008) test } \\
(p \text {-value })\end{array}$ \\
\hline Average returns & -0.88 & 1.96 & 2.84 & \\
\hline Standard dev. & 7.26 & 13.24 & 12.67 & \\
\hline Sharpe ratio & -0.122 & 0.147 & & 0.001 \\
\hline \multirow[t]{2}{*}{ CAPM alpha } & $-1.58^{*}$ & 0.665 & $2.11 * *$ & \\
\hline & $(-1.97)$ & $(0.63)$ & (2.39) & \\
\hline \multirow[t]{2}{*}{ Fama-French alpha } & $-1.59 *$ & 0.87 & $2.32 * *$ & \\
\hline & $(-1.84)$ & $(0.81)$ & $(2.35)$ & \\
\hline \multirow[t]{2}{*}{ Carhart alpha } & $-1.57 *$ & 1.07 & $2.50 * *$ & \\
\hline & $(-1.78)$ & $(0.93)$ & $(2.25)$ & \\
\hline
\end{tabular}

This table compares the portfolio performance of two different trading strategies over our full sample which spans the 2003:01-2012:05 period. The first strategy considers an investor who goes long on firms where their top directors have high ownership levels and show buying activity (given a negative past performance). If there is no buying activity from the top directors, the investor goes long on the risk-free asset instead. The second strategy assumes the same setup with the only difference being that the investor tracks the buying activity of top directors with low ownership levels. For both strategies, we obtain the Sharpe ratio and additionally report the corresponding risk-adjusted portfolio returns (alphas) for the CAPM, Fama-French three-factor model, and Carhart four-factor model. L/S denotes a portfolio strategy that goes long on low ownership buys and short on high ownership buys. Finally, we present the $p$-value of the Ledoit and Wolf (2008) statistic, which tests the null hypothesis that the Sharpe ratios of high and low ownership portfolios are equal. The table shows results for value-weighted portfolios. $t$ statistics are shown in parentheses and statistical significance at the 10\%, 5\%, and $1 \%$ level are indicated with $*, * *$, and $* * *$, respectively. 
Table 7. Robustness checks: Sample selectivity

\begin{tabular}{|c|c|c|c|}
\hline & \multirow[t]{2}{*}{$\begin{array}{l}\text { Panel A: } \\
\text { Financial crisis }\end{array}$} & \multicolumn{2}{|c|}{$\begin{array}{l}\text { Panel B: } \\
\text { Firm size }\end{array}$} \\
\hline & & Small firms & Large firms \\
\hline InsideTrade-Buy & $\begin{array}{c}-0.023^{* * *} * \\
(0.0005)\end{array}$ & $\begin{array}{c}-0.011 * * * \\
(0.002)\end{array}$ & $\begin{array}{c}-0.033^{* * *} \\
(0.010)\end{array}$ \\
\hline InsideTrade-Buy $*$ Crisis Period 1 & $\begin{array}{c}-0.130 * * * \\
(0.055)\end{array}$ & & \\
\hline InsideTrade-Buy $*$ Crisis Period 2 & $\begin{array}{l}-0.091 \\
(0.549)\end{array}$ & & \\
\hline InsideTrade-Sell & $\begin{array}{c}-0.019 * * * \\
(0.006)\end{array}$ & $\begin{array}{c}-0.070 * * * \\
(0.009)\end{array}$ & $\begin{array}{c}0.037 * * \\
(0.017)\end{array}$ \\
\hline InsideTrade-Sell $*$ Crisis Period 1 & $\begin{array}{c}-0.277 * * * \\
(0.018)\end{array}$ & & \\
\hline InsideTrade-Sell $*$ Crisis Period 2 & $\begin{array}{c}-3.316^{* * * *} \\
(1.211) \\
\end{array}$ & & \\
\hline Controls & YES & YES & YES \\
\hline Fixed effects & $\begin{array}{l}\text { Country \& } \\
\text { Month }\end{array}$ & $\begin{array}{c}\text { Country \& } \\
\text { Month }\end{array}$ & $\begin{array}{c}\text { Country \& } \\
\text { Month }\end{array}$ \\
\hline$R^{2}$ & 0.049 & 0.046 & 0.047 \\
\hline No of Obs. & 434801 & 144932 & 144933 \\
\hline
\end{tabular}

This table reports predictive regressions of stock returns using the insiders' buys and sells as predictive variables. The full sample spans the 2003:01-2012:05 period. Panel A looks into the effect of the recent global financial crisis on our results. Crisis Period 1 is a dummy variable that takes the value of 1 between September 2007 (the Nothern Rock bank run) and August 2008, and 0 otherwise. Crisis Period 2 is a dummy variable that takes the value of 1 between September 2008 (the Lehman Brothers collapse) and January 2009, and 0 otherwise. Panel B explores whether our results are driven by small or large firms. Firms that belong to the lower tertile (in terms of size) of our sample are classified as small, while those that belong to the top tertile are classified as large. Controls include the following variables: Size, BM, DY, Debt/TA, beta, $S \& P 500$, and Crisis dummy which is included only in Panel B (see appendix for variable definitions). Standard errors clustered both at the firm and country-level are reported in parentheses. Asterisks *, **, and $* * *$ indicate statistical significance at the $10 \%, 5 \%$, and $1 \%$ level, respectively. 
Table 8. Robustness checks: Institutional characteristics

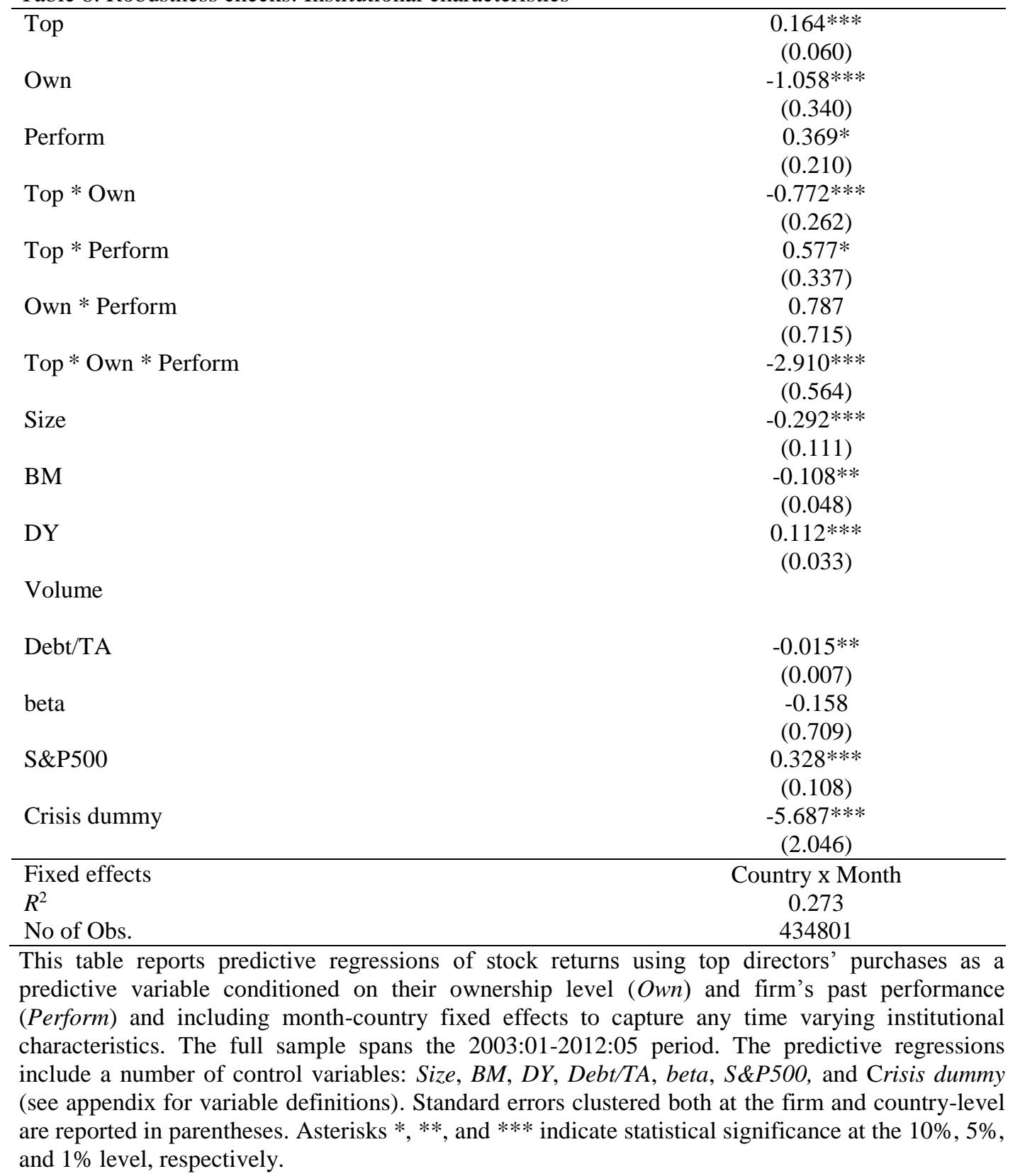


Table 9. Robustness checks: Blackout periods

\begin{tabular}{|c|c|c|}
\hline & All directors & Top directors \\
\hline & $(1)$ & $(2)$ \\
\hline CEO Buy & $\begin{array}{c}-0.030 * * * \\
(0.003)\end{array}$ & \\
\hline Chair Buy & $\begin{array}{c}-0.246 * * * \\
(0.068)\end{array}$ & \\
\hline Rest Buy & $\begin{array}{c}0.203 * * \\
(0.089)\end{array}$ & \\
\hline Top * Own * Perform & & $\begin{array}{c}1.728 \\
(1.430)\end{array}$ \\
\hline CEO Buy * Blackout & $\begin{array}{c}0.947 * \\
(0.516)\end{array}$ & \\
\hline Chair Buy * Blackout & $\begin{array}{c}4.308 * * * \\
(0.071)\end{array}$ & \\
\hline Rest Buy * Blackout & $\begin{array}{c}0.136 \\
(0.879)\end{array}$ & \\
\hline Top * Own * Perform * Blackout & & $\begin{array}{c}-109.762 * * * \\
(35.458)\end{array}$ \\
\hline Blackout & $\begin{array}{c}0.774 * * * \\
(0.264) \\
\end{array}$ & $\begin{array}{c}-1.957 * * \\
(0.869)\end{array}$ \\
\hline Other variables & Yes & Yes \\
\hline Fixed effects & $\begin{array}{c}\text { Country \& } \\
\text { Month }\end{array}$ & $\begin{array}{c}\text { Country \& } \\
\text { Month }\end{array}$ \\
\hline$R^{2}$ & 0.041 & 0.076 \\
\hline No of Obs. & 393034 & 12544 \\
\hline
\end{tabular}

This table reports predictive regressions of stock returns using insiders' (All directors and Top directors respectively) purchases as a predictive variable conditional on whether purchases take place during a blackout period or not. The blackout period is captured by a dummy variable that takes the value of 1 during the month preceding earnings announcement and 0 otherwise. The predictive regressions also include a number of other control variables: Size, BM, DY, Debt/TA, beta, S\&P500, and Crisis dummy (see appendix for variable definitions). Standard errors clustered both at the firm and country-level are reported in parentheses. Asterisks *, **, and *** indicate statistical significance at the $10 \%, 5 \%$, and $1 \%$ level, respectively. 


\section{Appendix}

Table A.1 Variable definitions and sources

\begin{tabular}{|c|c|c|}
\hline Variable & Definition & Source \\
\hline$R$ & Firm's monthly stock returns & DataStream \\
\hline $\begin{array}{l}\text { InsideTrade- } \\
\text { Buy }\end{array}$ & $\begin{array}{l}\text { Insiders' buying activity expressed in millions of } \\
\text { shares }\end{array}$ & DataStream \\
\hline $\begin{array}{l}\text { InsideTrade- } \\
\text { Sell }\end{array}$ & $\begin{array}{l}\text { Insiders' selling activity expressed in millions of } \\
\text { shares }\end{array}$ & DataStream \\
\hline CEO Buy & $\begin{array}{l}\text { Buying activity of CEO expressed in millions of } \\
\text { shares }\end{array}$ & DataStream \\
\hline Chair Buy & $\begin{array}{l}\text { Buying activity of Chair expressed in millions of } \\
\text { shares }\end{array}$ & DataStream \\
\hline Rest Buy & $\begin{array}{l}\text { Combined buying activity of the rest of firm's } \\
\text { directors expressed in millions of shares }\end{array}$ & DataStream \\
\hline Top & $\begin{array}{l}\text { Combined buying activity of CEO and Chair } \\
\text { expressed in millions of shares }\end{array}$ & DataStream \\
\hline Perform & $\begin{array}{l}\text { A dummy variable that takes the value of one if the } \\
\text { firm's return in the previous period is negative, and } \\
\text { zero otherwise }\end{array}$ & DataStream \\
\hline Own & Combined ownership level of CEO and Chair & DataStream \\
\hline Size & Logarithm of firm's market valuation & DataStream \\
\hline BM & Book-to-market ratio & DataStream \\
\hline DY & Dividend yield & DataStream \\
\hline Volume & $\begin{array}{l}\text { Logarithm of the number of shares traded for a stock } \\
\text { in a month }\end{array}$ & DataStream \\
\hline Debt/TA & Debt-to-total assets ratio & DataStream \\
\hline beta & The company's beta & DataStream \\
\hline S\&P500 & Return on the S\&P 500 index & DataStream \\
\hline Crisis dummy & $\begin{array}{l}\text { A dummy variable that takes the value one from } \\
\text { September } 2007 \text { onwards and zero otherwise }\end{array}$ & Own calculations \\
\hline Crisis Period 1 & $\begin{array}{l}\text { A dummy variable that takes the value of } 1 \text { between } \\
\text { September } 2007 \text { and August } 2008 \text {, and } 0 \text { otherwise }\end{array}$ & Own calculations \\
\hline Crisis Period 2 & $\begin{array}{l}\text { A dummy variable that takes the value of } 1 \text { between } \\
\text { September } 2008 \text { and January } 2009 \text {, and } 0 \text { otherwise }\end{array}$ & Own calculations \\
\hline EGD & $\begin{array}{l}\text { A dummy variable that takes the value of } 1 \text { if a } \\
\text { firm's earnings growth is positive in the previous } \\
\text { quarter, and } 0 \text { otherwise }\end{array}$ & $\begin{array}{l}\text { DataStream and } \\
\text { own calculations }\end{array}$ \\
\hline DVD & $\begin{array}{l}\text { A dummy variable that takes the value of } 1 \text { if a } \\
\text { firm's dividend growth is positive in the previous } \\
\text { quarter, and } 0 \text { otherwise }\end{array}$ & $\begin{array}{l}\text { DataStream and } \\
\text { own calculations }\end{array}$ \\
\hline TVD & $\begin{array}{l}\text { A dummy variable that takes the value of } 1 \text { if the } \\
\text { trading volume of a firm is lower than the average } \\
\text { trading volume of the previous twelve months and } 0 \\
\text { otherwise }\end{array}$ & $\begin{array}{l}\text { DataStream and } \\
\text { own calculations }\end{array}$ \\
\hline Blackout & $\begin{array}{l}\text { A dummy variable that takes the value of } 1 \text { if a } \\
\text { firm's earnings are announced in the following } \\
\text { month and } 0 \text { otherwise. }\end{array}$ & $\begin{array}{l}\text { DataStream and } \\
\text { own calculations }\end{array}$ \\
\hline
\end{tabular}

